\title{
Even the Rich go Hungry. Food Insecurity in the Highlands of Mt. Kenya
}

\author{
Michael Ndwiga ${ }^{1} \quad$ MaryBennah N Kuloba $^{2 *} \quad$ Lilian Nyambura $^{2} \quad$ Leonard Ngaithe $^{3}$ \\ 1.The University of Nairobi, School of Economics, P. O. Box 30197 - 00100,GPO, Nairobi Room GW 210 , \\ Kenya \\ 2.Utafiti International - Technology Research Company, P.O BOX 13506-00800, Paramount Plaza Nairobi, \\ Kenya \\ 3.Ministry of Trade, Kenya, P.O BOX 30418-00100, Social Security House, Block A Nairobi, Kenya
}

\begin{abstract}
Food insecurity is prevalent in most of the developing countries including Kenya. The design and implementation of sustainable strategies in addressing food insecurity requires an in depth understanding of its covariates. As a result, this paper estimated covariates of perceived of food insecurity among households in the slopes of Mt. Kenya, an area perceived to be food secure. In order to achieve this objective, proportionate stratified sampling method was used to select sample in Ngariama location, Kirinyaga and simple random sampling was utilized to identify individual households. The study utilized cross sectional data and a structured questionnaire was administered to a sample of 372. Probit regression was utilized to estimate the effect of each covariate on food insecurity. The paper found that $26 \%$ of the respondents were food insecure. Households that had land with title deeds, households who were educated and higher chances of been food secure.
\end{abstract}

Keywords: Food insecurity, Probit Regression Model

DOI: $10.7176 / \mathrm{FSQM} / 89-05$

Publication date: August 31st 2019

\section{Introduction}

Despite progress made by countries worldwide in addressing food insecurity, many household are still struggling to find enough food for survival especially in developing countries (Otsuka K, 2013; Majda B, 2013; Siamwalla Valdes, 1980). Changes in weather patterns and climatic condition have affected access to and availability of food due to the heterogeneous landscapes cutting across East Africa (Thornton et al., 2008; FAO 2016). These affects agricultural practices leading to low yield of staple food e.g maize, beans and cassava (Schlenker \& Lobell, 2010; Herrero et al., 2010, FAO 2016) in the process impacting on household dietary intakes due to overall food scarcity (Zipporah et al., 2014; Kathryn et al., 2014; FAO 2016). Households experience food insecurity when access to food decreases, food availability decreases or due to health-related issues or low uptake of balance diet (Kathryn et al., 2014). There have been tremendous efforts done by agencies such as JICA and the Alliance4Green Revolution in Africa over the past decades in innovative solutions to address food insecurity (Yamano et al., 2011; FAO 2014; Otsuka \& Larson, 2013). Communities have adopted innovative strategic practices such as timely access to climatic information, improved farming practices, financial inclusion practices among other measures (Beddington et al., 2011; Vermeulen et al., 2013).

The Sustainable Development Goal number two focuses on food insecurity; achieving zero hunger globally. In Kenya, agricultural sector is one of the building blocks of the big four agenda that the Kenyan government seeks to address. The industry contributes approximately $24 \%$ of the Gross Domestic Product (FAO, 2016; MOA, 2016, KNBS, 2018).The Government of Kenya is investing significantly in the agricultural sector trough provision of subsided fertilized, investing in irrigation schemes as a way of addressing food insecurity. The government has allocated more than Ksh.16.5 Billion to the agricultural sector through various irrigation schemes, rehabilitation of agricultural land and recovery of riparian land across the country etc. to cushion small-scale farmers against catastrophic climatic conditions, in addition to that, it has allocated additional 700,000 acres under maize, potato, rice and feeds production (KNBS, 2018). The country continues to experience food insecurity despite invested incurred, approximately over 10 million people are thought to be food insecure (UNAIDS 2010; IPCC, 2012; Jason et al., 2015).

Food security is potential of household in being self- sufficient accessing safe healthy food (Smith et al., 1992; KFSSG, 2008; FANTA, 2006; Tonukar \& Omotor, 2010; FAO, 2010). Current food insecurity related challenges are attributed to various determinants such as unreliable inadequate amount of rainfall due to changes in weather patterns, raising cost in food production, human encroachment to the forested and riparian land, raising global food prices and low purchasing power in communities (Herberich et al., 2012; Dube et al., 2014; FAO, 2016).

Studies have focused on communities endowed with limited natural resource such as arable land and water as a way of alleviating food security (Zipporah et al., 2014; Silvestri, 2015; FAO 2016). Changes in extreme weather events has posed challenge to the prevailing food insecurity especially in areas perceived to be food secure 
(Alinovi et al., 2010; Mathenge et al., 2010; Bryan et al., 2011; Herrera et al., 2018; Connor, 2017; FAO, 2016).

The study sought to find out covariates of perceived food insecurity especially in areas perceived to be food secured, previous researchers have focused on access and affordability to food in arid and semi-arid areas. Perceived food secured areas have in the process become vulnerable. The information is relevant to policymakers in tailoring national food security policies in providing solutions to its people (Alinovi et al., 2010).

\section{Literature Review}

Globally, as countries continue working to be food secure, new emerging issues has develop, areas thought to be food secure are now experiencing food shortage (Josephson et al., 2014). In developing countries, small scale farmers found in the areas perceived to be food secure contribute to the countries' food safety nets in feeding its people despite the challenges that they encounter during food production (Nagayet, 2005; Evans et al., 2018; Niranjan et al., 2018). Land set aside for agricultural purposes has diminished over time due to the ever rising population especially in the rural areas (Population Reference Bureau, 2012; Jayne et al., 2012).

The continuous increase in population has seen a reduction in the size of land an individual inherits from the family (Jayne et al., 2010; Karol, 2013), this posed a challenge as land allocation for agricultural purpose has reduced in size. Less land reserved for agricultural purposes, food productivity decreases, inadequate markets, slow technology adoption and changes in weather patterns and climate impacts negatively on accessibility and affordability of food for consumption (Di Falco \& Chavas, 2009; Salvatore, 2014; Josephson et al., 2014). Land tenure among small scale farmers poses a challenge investing in farms (Holden \& Yohannes, 2002; Deininger \& Jin, 2006; Pender \& Gebremedhin, 2007; Ali et al., 2011; Jayne et al., 2012). The continued vast disparities in landholding size among smallholder farmers contributes to a skewed patterns in farm production and marketed surplus. It is perceived that more than half of the rural population are vulnerable to food insecurity due to challenges in accessing and utilizing food; owing less than a hectare of land, a high percentage of farmers in densely populated communities find challenges in owing land through inheritance, even in communities where a land is idle (Dreschel et al., 2001; Jordan Chamberlin et al., 2012).

Numerous research have documented need to invest in small holder famers, it is seen as a major pathway from a semi-substance agrarian society to a more prosperous, food secure, and diversified economy (Stanford Research Paper, 2012). In addition to that, studies have demonstrated how initial distribution of assets affect the rate of economic growth, but it also affects the poverty-reducing effects of the growth that does occur. Majority of small farm household obtains little portion of their earnings from off-farm utilizes, they face volatile conditions due to the changes in weather conditions, and market related events to the high cost of productions (FAO, 2008). This in turn negatively impacts on manufacturing systems, food markets and local economies thus negating food security. Numerous research have indicated that majority of this farmers who are not only producers but also consumers of the produce (FAO, 2008). Public expenditures on farm input subsidies and price supports benefits large scale farmers negating small scale farmers (Banful, 2011). This poses challenge to small-scale farms who have limited access to funds to support agricultural activities (Salvatore, 2014). In addition to that there is capital constraints on farm intensification, lowering productivity, small farms reduce fallows and soil nutrients depletion contributing to the declining per capita food production (Christiansen et al., 2011). There is need to improve and restore soil fertility, hence greater use of conventional inorganic fertilizers, while necessarily, certainly will not be sufficient to reach attainable yields.

Studies has shown that food insecurity is affected negatively by household income, age, education and head of household education (Bashir et al. 2012; Arene, 2008). De Muro \& Burchi, (2007) found out that famine is correlated with education deprivation. In addition, association is highest at primary level and reduces as level of education increases. Education plays an active role in developing individuals' capabilities thus becomes a mechanism of tackling food insecurity. Investing in quality primary education will enable communities especially among small scale farmers to have an open mindset to adopt modernized farming practices, embrace new agricultural revolution which will contribute significantly in achieving SDGs' on ending hunger and achieving food security and improved nutrition, given that there are more people in rural areas with high level of poverty. At the slope of Mt. Kenya, household monthly income is very low, thus becoming a challenge to the head of household in providing for their family and at the same time partake in agricultural work which is labour intensive. Income as a covariant of food insecurity determines level of investment that makes community to engage in agricultural practices (Crush et al., 2012). Another aspect of food insecurity is gender, it is perceived that female headed household tends to be food insecure (Franye, 2009; Kassiel et al., 2012; Carter et al., 2012; Kassie et al., 2012). The aspect of gender, landholding and food insecurity is important to able to understand how gender and perceived food security as related.

\subsection{Perceived Food Insecurity}

Over the past decade to date, research have focused on food insecurity in semi-arid and arid regions leaving areas perceived as food secure become vulnerable to food insecurity (Siamwalla Valdes, 1980; Otsuka K, 2013; Silvestri, 
2015; FAO 2016). In highland areas, for rain fed produce, reliance on weather changes is likely to affect production, thus affecting accessibility (Chamberlin et al., 2014). Ricardian method has been adopted as a way to link climate change and food insecurity, to provide insights to policy makers in promoting target policies (Mendelsohn et a., 1994; Stage, 2010; DiFalco et al 2012; Bryan et al., 2013). Estimates of agricultural performance include land value and farm revenues. It highlights the negative effective of climate on agricultural land how farmers try to adapt to it (Mendleson, 1994).

One of the weakness of the Ricardian model is that, it fails to take into account transaction cost when a farmer makes decision to switch production abruptly (Barnwal \& Kotani, 2010). Although its demerits are weak in climate change studies conducted at a lower level, focusing in developing countries where segments of the territory is controlled by a single meteorological station (Di Falco et al., 2011; Cline, 1996; Kurukulasuriya \& Mendelsohn, 2006). Although the Ricardian approach has been successful in 27 countries, (Mendelsohna \& Dinar, 2009), it is used annually. Deschenes \&Greenstone, 2007 states that for concrete results overtime on climate change and food insecurity, however Masset \& Mendleson, 2011 states that weather changes are limited farmers are not in position to adapt in a short time (Masset \& Mendelson, 2011).

\subsection{Covariates of Food Insecurity}

Farmers relate food insecurity to land size, title deeds, extension officer, gender, age, education of an individual affects ability of households head to provide for its' family (Maddison, 2007). Using the Heckman's probit model, analysis done by Maddison, 2007 on selected farmers at the slope of Mt. Kenya shows that gender affects access to be food secure. The model collaborates with the study in that household led by women are thought to be food insecure compared to the male (Kassie et al., 2012), this can be related to gender disparities in agriculture such as land rights and relation status (Kassie et al., 2012), Married couples are perceived to be food secured compared to single women (Elijah, 2010; Kassie et al., 2012). Location of the farmers in the communities limits their contacts with agricultural extension officer this limits their access to government information in terms of climate change (Frelat et al., 2016). Household location affects the supply and demand of food consumption, access to markets. According to Abebaw, 2003, the older an individual is, the more knowledgeable ones is regarding food insecurity (Abebaw, 2003; Idris, 2012). An elder person is in position to understand dynamics that have occurred over time that have contributed to food insecurity.

Diversification is important in addressing food insecurity e.g coffee, tea, and maize (Maddison, 2007). This agrees with studies done by other researchers (Bryan et al., 2009; Salvatore, 2014). It is also perceived that crop diversification is a strategy for cost cutting measures as it is the cheapest means to adaption inclusive livestock keeping (Seo \& Mendelsohn, 2008; Deressa et al., 2009; Adugna \& Wogayehu, 2011). According to Boserup, 1965 , size of land dedicated for agricultural purpose has diminished over time due to human encroachment contributes to prevailing food insecurity (Boserup, 1965). Land holding decreases in size from one generation to another as the population increase (Arene \& Anyaeji, 2010; Jayne et al., 2012). Hence over time, the available land for agricultural purposes reduces. The FAO, 2016 report states without education, impedes employability, productivity and earning capacity, contributing to food insecurity. Investing in education helps to promote agency, the expected long term effect of education is seen through social and institutional change De Muro \& Burchi, (2007) ; it facilities accessing public information as it makes individual think more beyond the norm. In terms of utilizing the information transmitted via print and digital media, individuals can read, write and understand information being communicated if there are more educated and knowledgeable. A lot of benefits can be derived from education, it brings inner contribution to food security, reducing reliance for support, feeling shamed and embarrassed; it also highlights the need to invest in education of women and being involved in agricultural activities as a way of catalyzing development (Razavi, S. (2012). Changes in weather patterns and climatic conditions increases vulnerability of community dependency on agricultural production (Paul et al, 2014). In a recent study conducted, it was found out that the existing land and water resources experiences pressure from changes in extreme weather and climatic conditions to poor land use and management practices (Notter et al., 2007; SWFEDO, 2012; J. Schmocker et al., 2015). Continuous human encroachment to the riparian land coupled with high population density, increase agricultural practices necessitates increase demand for irrigation as an alternative approach to water deficit and water loss which in turns leads to overutilization and increasing water conflicts (Wiesmann et al., 2000; LRWUA, 2004; SWFEDO, 2012; Paul et al., 2014).

\subsection{Methodology}

\subsection{Study Area}

The study was conducted in Kirinyaga County, which is one of the 47 Counties in Kenya. Kirinyaga County covers an area of 1,478.1 square kilometers and is located in the South of Mt. Kenya. Mt. Kenya greatly influences the landscape of the county as well as other topographical features. The county comprises of three ecological zones namely lowland, midland and highland. Not only is the highland area adjacent to Mt. Kenya forest, receives adequate rainfall but also it is well covered with six major rivers that supply it with water for consumption and 
irrigation (CGK, 2017).

Kirinyaga County had Human Poverty Index (HPI) of $25.2 \%$ in comparison to national HPI of $29.1 \%$ showing that the county is relatively rich. The county also has low poverty incidence. It has a population of approximately 528,054 people majority of whom practice small-scale farming. Agriculture is the main source of income and food for most families. Most of the produce is for own consumption with very few surpluses taken to the market (Hijmans et al., 2005; Huho et al., 2012). The county faces several challenges among them, high land fragmentation, increased frequency and intensity of climate change, wildlife conflicts and rising cost of agricultural production. All these factors have serious implications on food security at the household level.

\subsection{Sampling Methods and Data Collection}

Kirinyaga County has four constituencies and twenty county assembly wards. The study used purposive sampling to select one constituency that largely covers the highland areas. Gichugu constituency was selected and random sampling was used to select one ward out of five wards in the constituency. The ward chosen, Ngariama ward, had a population of 18,064 and 5,411 wards. The unit of analysis for this paper was households. Given a population of 5,411 households, the paper utilized Yamane (1967) sample size determination formula with a precision error of 0.05 to get a sample of 372. Proportionate stratified sampling method was used to select the households based on each sub location in Ngariama ward. With assistance of sub-chiefs and village elders, a list of all households was compiled and simple random sampling utilized to identify individual households. The study adopted a cross sectional survey design and a structured questionnaire was utilized to collect data (Mugenda, 1999; Kombo \& Tromp, 2009). The questionnaire capture information on socio-economic characteristics of the household and information related to the food security situation. The questionnaire was pilot tested and found to be reliable and valid.

\subsection{Econometric Specification}

The empirical specification is based on Boserup (1965) and random utility theories. The utility an individual i obtains from been food secure could be specified as a function of deterministic $\left(V_{i}\right)$ and stochastic $\left(\varepsilon_{i}\right)$ components that capture the unobservable.

$U_{i}=V_{i}+\varepsilon_{i}$

The deterministic component is a linear index of individual characteristics $\left(X_{i}\right)$. Given this specification, an individual will prefer to be food secure if and only if the utility derived from been food secure is greater than utility derived from been food insecure. This analogy can be used to model food insecurity by employing probability models (Greene, 2012). This paper measured perceived food insecurity as a dummy variable where 1 denoted food insecurity and 0 otherwise. Based on the fact that the paper has dummy dependent variable, probit or logit regression could be employed to investigate the covariates of food insecurity. The paper estimated probit regression model that was specified as;

$Y^{*}=\beta_{0}+\beta_{1} X_{i}+\varepsilon_{t}$

Where $Y^{*}$ denotes a dummy variable (where 1 is food insecure and 0 otherwise), $\mathrm{X}$ is a vector of covariates that include; individual, household and farm characteristics, and social capital. $\beta$ 's are parameters to be estimated, $\varepsilon$ is the stochastic error term and $\mathrm{i}$ denotes the individual household. Equation 2 was estimated using maximum likelihood. The paper conducted the diagnostic tests such as; heteroscedasticity, omitted variable error and multicollinearity.

\subsection{Findings and Discussions 4.1 Descriptive Statistics}

According to the study finding, perception of food insecurity is determined by location of the communities Rungeto (45\%), Kabri (39\%), Thirikwa (29\%) with families living in Rungeto being statistically significant. $26 \%$ of the respondent are perceived to be food secure, owing a land title deed $(71 \%)$ is perceived to be food secure. Having livestock $(81 \%)$ was seen as being food secured in community, in addition to that majority of the farmers $(97 \%)$ are members of a farmers group. Farmers have access to extension services $(65.6 \%)$. The research also found out that household that are headed by male are perceived to be food secured $(70.3 \%)$ compared to the female headed house. An individual who is married (78.9\%) is perceived as food secured compared to single (10\%) and divorced $(20 \%)$.

The more education an individual is the less risk in being food insecure. According to the study, individuals living in Nyageni (51.6\%) are perceived to be food secure in comparison to communities in Rungeto (30.9\%), Kabari (6.8\%) and Thirikwa (10.7\%). The study also found out that an individual who is employed is more likely to be food secured. In addition to that, majority of the farmers at $(74.5 \%)$ have access to credit. This increasing their agricultural activities in the area as they are able to invest in farm inputs both for commercial and household consumption purpose. Farmers have access to information with regards to food security.

Majority of the respondents indicated that their main source of information was radio $(96.1 \%)$, followed by 
television $(50.9 \%)$. This could imply that majority of the farmers owned radio and television which airs in their vernacular languages where information on food security measures can be easily be accessed and utilized. The study also found that, farmers engage extensively in cash crop activities such as coffee (97.6\%), tea (61.5\%), horticultural practices $(67.9 \%)$, maize $(51.4 \%)$ and beans $(43.1 \%)$. The study area around the slopes Mt. Kenya which was characterized by indigenous forest cover. This has greatly influences the landscape, soil composition and making the areas a fertile ground for agricultural practices thus being food secure community. In the recent past, with rapid urbanization and migration, the areas has experienced food insecurity which is not otherwise the norm.

\section{Table 1: Descriptive Statistics}

\begin{tabular}{|c|c|c|c|c|c|}
\hline Variable & Obs & Mean & Std. Dev. & Min & Max \\
\hline Perceived Food insecurity ( $1=$ food insecure, 0 otherwise $)$ & 337 & 0.258 & 0.438 & 0 & 1 \\
\hline Land size in Acres & 329 & 1.787 & 1.676 & 0.25 & 10 \\
\hline $\begin{array}{l}\text { Land has title deed } \\
(1=\text { title deed, } 0 \text { otherwise })\end{array}$ & 329 & 0.708 & 0.455 & 0 & 1 \\
\hline $\begin{array}{l}\text { Own livestock } \\
(1=\text { own livestock, } 0 \text { otherwise })\end{array}$ & 337 & 0.810 & 0.393 & 0 & 1 \\
\hline Member of farmer group ( 1 = member of farmer group, 0 otherwise $)$ & 337 & 0.973 & 0.161 & 0 & 1 \\
\hline $\begin{array}{l}\text { Received extension services } \\
(1=\text { received extension services, } 0 \text { otherwise })\end{array}$ & 337 & 0.656 & 0.476 & 0 & 1 \\
\hline Gender ( $1=$ Male, 0 female $)$ & 337 & 0.703 & 0.457 & 0 & 1 \\
\hline Age in years & 337 & 45.18 & 11.680 & 12 & 89 \\
\hline Marital -Married & 337 & 0.789 & 0.408 & 0 & 1 \\
\hline Marital-Single & 337 & 0.100 & 0.302 & 0 & 1 \\
\hline Marital-Divorced & 337 & 0.200 & 0.313 & 0 & 1 \\
\hline Years in education & 335 & 11.30 & 2.477 & 0 & 22 \\
\hline Location 1-Rungeto & 337 & 0.309 & 0.463 & 0 & 1 \\
\hline Location 2- Kabari & 337 & 0.068 & 0.253 & 0 & 1 \\
\hline Location 3- Thirikwa & 337 & 0.107 & 0.309 & 0 & 1 \\
\hline Location 4- Nyangeni & 337 & 0.516 & 0.500 & 0 & 1 \\
\hline Employment Status & 337 & 2.024 & 0.203 & 1 & 3 \\
\hline $\begin{array}{l}\text { Monthly income } \\
\text { (In thousand Ksh.) }\end{array}$ & 337 & 28.43 & 77.05 & 0.003 & 1000 \\
\hline $\begin{array}{l}\text { Credit access } \\
(1=\text { yes, } 0 \text { otherwise })\end{array}$ & 337 & 0.745 & 0.437 & 0 & 1 \\
\hline $\begin{array}{l}\text { Owned radio } \\
(1=\text { yes, } 0 \text { otherwise })\end{array}$ & 334 & 0.961 & 0.194 & 0 & 1 \\
\hline $\begin{array}{l}\text { Owned television } \\
(1=\text { yes, } 0 \text { otherwise })\end{array}$ & 334 & 0.509 & 0.500 & 0 & 1 \\
\hline Grows coffee & 327 & 0.976 & 0.155 & 0 & 1 \\
\hline
\end{tabular}




\begin{tabular}{|c|c|c|c|c|c|}
\hline Variable & Obs & Mean & Std. Dev. & Min & Max \\
\hline \multicolumn{6}{|l|}{ ( $1=$ Yes, 0 otherwise) } \\
\hline $\begin{array}{l}\text { Grows tea } \\
(1=\text { Yes, } 0 \text { otherwise })\end{array}$ & 327 & 0.615 & 0.487 & 0 & 1 \\
\hline $\begin{array}{l}\text { Grows maize } \\
\text { (1=yes, } 0 \text { otherwise })\end{array}$ & 327 & 0.514 & 0.501 & 0 & 1 \\
\hline $\begin{array}{l}\text { Grows horticulture } \\
\text { (1=yes, } 0 \text { otherwise })\end{array}$ & 327 & 0.679 & 0.468 & 0 & 1 \\
\hline $\begin{array}{l}\text { Grows beans } \\
\text { (1=yes, } 0 \text { otherwise })\end{array}$ & 327 & 0.431 & 0.496 & 0 & 1 \\
\hline
\end{tabular}

\subsection{Probit Regression Model Results}

The table 2 shows the probit regression output for the covariates of food insecurity. Multivariable response such as education, employment, gender, location and other land variables such as title deed, size, contributes to food insecurity in the study areas. Results from regression model indicates that title deed $(53 \%)$ is statistically significant to food security According to the study, access to title deeds negatively affects food security, when a farmer has no tittle deed, he or she perceived to be food insecure.

This results agrees with Headey \& Jayne (2014) who note that in recent years, scarcity of land has become an agenda due to densely populated rural communities were off-farm activities are limited with continued reliance on low agricultural yields that cannot sustain people's livelihood, coupled with poor land governance infrastructure where allocation is done to the highest bidder (Deininger \& Byerlee, 2011; Headey \& Jayne 2014). This is contrary to Jayne et al., 2016, who states that lack of land tenure possess a challenges to small scale farmers in terms of farm investments due to uncertainty.

Disparities in landholding size within smallholders farming leads to highly concentrated and skewed patterns of farm production and marketed surplus as they are major producers of food crops especially in the rural communities ( Pender \& Gebremedhin, 2007; Ali et al., 2011; Jayne et al., 2012; Jordan Chamberlin et al., 2012). However this contradicts studies done by Frelat et al., (2016) who states that food security is not determined by land size nor title deeds but determined by the degree of market access.

The study indicated that years in education statistical significantly to food security $(12.9 \%)$ thus negating food security. A reduction in years of schooling of an individual is perceived as being vulnerable to food insecurity. This study agrees with findings of Abid et al. 2016 who states that farmers can adopted resilience strategies to food insecurity if they are more educated and knowledgeable. The more educated a farmer the more likelihood of being knowledgeable on food insecurity. Education gives the farmer the ability to read and understand concepts of food insecurity and adopt sustainable strategies compared to famers with low level of no education. Alinovi, et.al., (2010) concludes that farmers and household should be empowered in livelihood strategies focusing on the building resilience to food insecurity, supporting access to assets, developing an enabling policy and institutional environment for household to thrive. Governments and international institutions should therefore invest more in education of its people especially among the rural communities.

The results showed that male headed household (4\%) are perceived to be food secure compared to female headed household. In previous studies done, results has shown that female headed household especially in areas with traditional practices have challenge in accessing land, livestock, credit, education, markets, and extension services(Odame et al., 2002; Razavi, 2012). The study also found out that in a widowed house, in the case of death of a male household head, perceived food insecurity is at $26 \%$. This agrees with research done by (Elijah, 2010) that indicated that the widow will be compelled to dispose of assets as well reduction in extra household support linked to the loss of husband. According to Meinzen-Dick et al., 20110, if household is female (87\%), vulnerability is high compared to males, especially in traditional set up, male are given priority when assets are subdivide during divorce or death compare to female (Meinzen et al., 2013). According to the responses, accessing extension services $(27 \%)$ determines what the community perceived as food insecure, if an individual fails to access the service of an extension officer, the perception of food insecurity tends to be high. This is in in line with what Githini et al., 2011 states regarding inequalities gender difference in accessing extension services especially among the females is limited (Githinji et al., 2011). 
Table 2: Probit Regression Results

\begin{tabular}{|c|c|}
\hline Variables & Coefficients \\
\hline \multirow[t]{2}{*}{ Land size in acres } & -0.0512 \\
\hline & $(0.0565)$ \\
\hline \multirow[t]{2}{*}{ Title deed ( $1=$ yes, 0 otherwise $)$} & $-0.5307 * * *$ \\
\hline & $(0.1903)$ \\
\hline \multirow[t]{2}{*}{ Livestock ownership ( $1=$ yes, 0 otherwise) } & 0.1649 \\
\hline & $(0.2248)$ \\
\hline \multirow[t]{2}{*}{ Extension services ( $1=$ yes, 0 otherwise) } & -0.2746 \\
\hline & $(0.1778)$ \\
\hline \multirow[t]{2}{*}{ Gender (1= Male, 0 Female $)$} & 0.0424 \\
\hline & $(0.1936)$ \\
\hline \multirow[t]{2}{*}{ Age in years } & -0.0056 \\
\hline & $(0.0376)$ \\
\hline \multirow[t]{2}{*}{ Age square } & -0.0001 \\
\hline & $(0.0004)$ \\
\hline \multirow[t]{2}{*}{ Marital Status (Single) } & -0.1693 \\
\hline & $(0.3042)$ \\
\hline \multirow[t]{2}{*}{ Marital Status (widowed) } & 0.2632 \\
\hline & $(0.2839)$ \\
\hline \multirow[t]{2}{*}{ Years in education } & $-0.1290^{* * *}$ \\
\hline & $(0.0360)$ \\
\hline \multirow[t]{2}{*}{ Location- Rungeto } & $0.4548 * *$ \\
\hline & $(0.2119)$ \\
\hline \multirow[t]{2}{*}{ Location- Kabari } & 0.3911 \\
\hline & $(0.3530)$ \\
\hline \multirow[t]{2}{*}{ Location- Thirikwa } & 0.2969 \\
\hline & $(0.2850)$ \\
\hline \multirow[t]{2}{*}{ Monthly Income (in thousands Ksh.) } & 0.0009 \\
\hline & $(0.0011)$ \\
\hline \multirow[t]{2}{*}{ Credit Access ( $1=$ yes, 0 otherwise $)$} & 0.2567 \\
\hline & $(0.2106)$ \\
\hline
\end{tabular}




\begin{tabular}{ll}
\hline Variables & Coefficients \\
\hline Owned Radio $(1=$ yes, 0 otherwise $)$ & -0.0170 \\
Owned Television $(1=$ yes, 0 otherwise) & $-0.4298)$ \\
Grows Tea $(1=$ yes, 0 otherwise $)$ & $(0.1689)$ \\
Grows Maize $(1=$ yes, 0 otherwise $)$ & 0.1154 \\
Grows Horticulture $(1=$ yes, 0 otherwise $)$ & $(0.1807)$ \\
Constant & -0.1823 \\
Observations & $(0.1836)$ \\
\hline
\end{tabular}

Standard errors in parentheses, ${ }^{* * *} \mathrm{p}<0.01,{ }^{* *} \mathrm{p}<0.05,{ }^{*} \mathrm{p}<0.1$

\section{Conclusion}

The results of study findings indicated that $25.8 \%$ of the respondents were perceived to be food insecure in communities of abundance and plenty. This is a call to action on sustainable intervention in addressing food insecurity in areas perceived to be food secure. The socio economic factors that negatively significant related to food insecurity were years of schooling, communites location near Rungeto and title deeds. Therefore, interventions intended to help food insecure households in the area have to give priority to household with no title deed to own land, as land ownshership is seen as an assest. Furthermore, building capacity of communites through scholing should be a key as a way of adressing food insecurity. Improving educational level of rural communites is significant in overall effort on food security, this recquires collective accoutability and particiaption fom stakeholders involved, greater investments in resources. Farmers should be empowered on modernised farming techniques that easily be adopted and utilised as a strategy to mitigate food insecurity. According to the findings communites in Rungeto are seen to have a negative association to food insecurity. The areas is well knonw for vast land of coffe plantation and yet it is ecpereince food insecurity. In conclusion, national and county governemnt should intergrate food insecurity measure in highland regions, farmers should be allowed to own land on small scale despite the areas being considered for cash purposes in food production. The paper highights the needs to invest in education level of communites, education is one of the pillars that policy makers should adress in fighting food insecurity. Further more, small scale industries in rural areas should be encourged through promotion of farming activities, encourage both farm and non farm employment activities. This could shift proportion of households from entire reliance on land and invsting on cash crop only.

\section{REFERENCES}

Abebaw, S. (2003). Dimensions and determinants of food security among rural households in Dire Dawa, Eastern Ethiopia. An MSc Thesis Presented to the School of Graduate Studies of Alemaya University. 152p.

Adano, W. R., Dietz, T., Witsenburg, K., \& Zaal, F. (2012). Climate change, violent conflict and local institutions in Kenya's drylands. Journal of Peace Research, 49(1), 65-80.

Affix, T., Liwenga, E., \& Kwezi, L. (2014). Rainfall-induced crop failure, food insecurity and out-migration in Same-Kilimanjaro, Tanzania. Climate and Development, 6(1), 53-60.

Ahmed, K. D., Jema, H., \& Lemma, Z. (2018). Determinants of food insecurity and coping strategies of rural households: The case of Shalla District, West Arsi Zone, Oromia Region, Ethiopia. Journal of Development and Agricultural Economics, 10(6), 200-212.

Alinovi, L., D’errico, M., Mane, E., \& Romano, D. (2010, June). Livelihoods strategies and household resilience 
to food insecurity: An empirical analysis to Kenya. In conference organized by the European Report of Development, Dakar, Senegal, June (pp. 28-30).

Alkire, S., Meinzen-Dick, R., Peterman, A., Quisumbing, A., Seymour, G., \& Vaz, A. (2013). The women's empowerment in agriculture index. World Development, 52, 71-91.

Arene, C. J., \& Anyaeji, R. C. (2010). Determinants of food security among households in Nsukka Metropolis of Enugu State, Nigeria. Pakistan Journal of Social Sciences, 30(1), 9-16.

Banful, A. B. (2011). Old problems in the new solutions? Politically motivated allocation of program benefits and the "new" fertilizer subsidies. World Development, 39(7), 1166-1176.

Barnwal, P., \& Kotani, K. (2010). Impact of variation in climatic factors on crop yield: A case of rice crop in Andhra Pradesh, India. Economics and Management series, 17.

Bashir, M. K., Schilizzi, S., \& Pandit, R. (2012). Are the determinants of food insecurity for landless households different from that of other rural households? Pak. J. Agri. Sci, 49(3), 393-400.

Below, T. B., Mutabazi, K. D., Kirschke, D., Franke, C., Sieber, S., Siebert, R., \& Tscherning, K. (2012). Can farmers' adaptation to climate change be explained by socio-economic household-level variables? Global Environmental Change, 22(1), 223-235.

Bennett, R., Zevenbergen, J., Lengoiboni, M., Waymuba, G. O., \& Omondi, S. (2013, June). The pastoralist's parcel: towards better land tenure recognition and climate change response in Kenya's dry lands. In FIG Working Week.

Benson, C., \& Clay, E. (2004). Understanding the economic and financial impacts of natural disasters. The World Bank.

Bertsias, G. K., Tektonidou, M., Amoura, Z., Aringer, M., Bajema, I., Berden, J. H., \& Ferrario, F. (2012). Joint European League against Rheumatism and European Renal Association-European Dialysis and Transplant Association (EULAR/ERA-EDTA) recommendations for the management of adult and paediatric lupus nephritis. Annals of the rheumatic diseases, 71(11), 1771-1782.

Boserup, E. (1965). The Conditions of Agricultural. Growth, 691-701.

Bremner, J. (2012). Population and food security: Africa's challenge. Population Reference Bureau Policy Brief.

Bryan, E., Deressa, T. T., Gbetibouo, G. A., \& Ringler, C. (2009). Adaptation to climate change in Ethiopia and South Africa: options and constraints. Environmental Science and Policy, 12(4), 413-426

Bryan, E., Ringler, C., Okoba, B., Roncoli, C., Silvestri, S., \& Herrero, M. (2013). Adapting agriculture to climate change in Kenya: Household strategies and determinants. Journal of Environmental Management, 114, 2635 .

Campbell, B. M., Vermeulen, S. J., Aggarwal, P. K., Corner-Dolloff, C., Girvetz, E., Loboguerrero, A. M., ... \& Wollenberg, E. (2016). Reducing risks to food security from climate change. Global Food Security, 11, 3443.

Carraher, S. (2014). Kathryn Harrigan, Management History, and Michael Peng. Journal of Management History, $20(3)$.

Chamberlin, J., Jayne, T. S., \& Headey, D. (2014). Scarcity amidst abundance? Reassessing the potential for cropland expansion in Africa. Food Policy, 48, 51-65.

Crépin, F., \& Trauzettel, B. (2014). Parity measurement in topological Josephson junctions. Physical review letters, 112(7), 077002.

Crush, J. S., \& Frayne, G. B. (2011). Urban food insecurity and the new international food security agenda. Development Southern Africa, 28(4), 527-544.

Deininger, K., \& Byerlee, D. (2011). Rising global interest in farmland: can it yield sustainable and equitable benefits? The World Bank.

Deininger, K., \& Jin, S. (2006). Tenure security and land-related investment: Evidence from Ethiopia. European Economic Review, 50(5), 1245-1277.

Deressa, T. T., Hassan, R. M., \& Ringler, C. (2011). Perception of and adaptation to climate change by farmers in the Nile basin of Ethiopia. The Journal of Agricultural Science, 149(1), 23-31.

Deschênes, O., \& Greenstone, M. (2007). The economic impacts of climate change: evidence from agricultural output and random fluctuations in weather. American Economic Review, 97(1), 354-385.

Di Falco, S., \& Chavas, J. P. (2009). On crop biodiversity, risk exposure, and food security in the highlands of Ethiopia. American Journal of Agricultural Economics, 91(3), 599-611.

Di Falco, S., Veronesi, M., \& Yesuf, M. (2011). Does adaptation to climate change provide food security? A micro-perspective from Ethiopia. American Journal of Agricultural Economics, 93(3), 829-846.

Di Falco, S., Yesuf, M., Kohlin, G., \& Ringler, C. (2012). Estimating the impact of climate change on agriculture in low-income countries: household level evidence from the Nile Basin, Ethiopia. Environmental and Resource Economics, 52(4), 457-478.

Dinar, A., Hassan, R., Kurukulasuriya, P., Benhin, J., \& Mendelsohn, R. (2006). The policy nexus between agriculture and climate change in Africa. A synthesis of the investigation under the GEF/WB Project: 
Regional climate, water and agriculture: Impacts on and adaptation of agro-ecological systems in Africa. CEEPA Discussion Paper No. 39.

Domodar, G. N., \& Dawn, C. P. (2004). Basic Econometrics.

Doss, C., Summerfield, G., \& Tsikata, D. (2014). Land, gender, and food security.

Dube, A. K., Haji, J., \& Zemedu, L. (2018). Determinants of food insecurity and coping strategies of rural households: The case of Shalla District, West Arsi Zone, Oromia Region, Ethiopia. Journal of Development and Agricultural Economics, 10(6), 200-212.

FAO, I. (2016). WFP (2015), the State of Food Insecurity in the World 2015. Meeting the 2015 international hunger targets: taking stock of uneven progress. Food and Agriculture Organization Publications, Rome.

Foeken, D. W. J., \& Mboganie-Mwangi, A. (2000). Increasing food security through urban farming in Nairobi.

Francioli, L. C., Menelaou, A., Pulit, S. L., Van Dijk, F., Palamara, P. F., Elbers, C. C., \& Deelen, P. (2014). Whole-genome sequence variation, population structure and demographic history of the Dutch population. Nature genetics, 46(8), 818.

Frelat, R., Lopez-Ridaura, S., Giller, K. E., Herrero, M., Douxchamps, S., Djurfeldt, A. A., \& Rigolot, C. (2016). Drivers of household food availability in sub-Saharan Africa based on big data from small farms. Proceedings of the National Academy of Sciences, 113(2), 458-463.

Githinji, M., Konstantinidis, C., \& Barenberg, A. (2011). Small and as productive: Female-headed households and the inverse relationship between land size and output in Kenya. Economics Department Working Paper Series.

Granger, D. A., Hood, K. E., Dreschel, N. A., Sergeant, E., \& Likos, A. (2001). Developmental effects of early immune stress on aggressive, socially reactive, and inhibited behaviors. Development and Psychopathology, 13(3), 599-610.

Herberich, D. H., \& List, J. A. (2012). Digging into background risk: experiments with farmers and students. American Journal of Agricultural Economics, 94(2), 457-463.

Herrera, C., Ruben, R., Dijkstra, G., \& Ruben, R. (2018). Climate variability and vulnerability to poverty in Nicaragua, 6544.

Higham, T., Douka, K., Wood, R., Ramsey, C. B., Brock, F., Basell, L., \& Bergman, C. (2014). The timing and spatiotemporal patterning of Neanderthal disappearance. Nature, 512(7514), 306.

Hijmans, R.J., Cameron, S.E., Parra, J.L., Jones, P.G., Jarvis, A., 2005. Very high resolution interpolated climate surfaces for global land areas. Int. J. Climatol. 25 (15), 1965-1978.

Holden, S., Shiferaw, B., \& Pender, J. (2006). Policies for Poverty Reduction, Sustainable Land Management, and Food Security: A Bioeconomic Model with Market Imperfections. Strategies for Sustainable Land Management in the East African Highlands, 333.

Horlings, L. G., \& Marsden, T. K. (2011). Towards the real green revolution? Exploring the conceptual dimensions of a new ecological modernisation of agriculture that could 'feed the world'. Global environmental change, 21(2), 441-452.

Huho, J. M., Ngaira, J. K., Ogindo, H. O., \& Masayi, N. (2012). The changing rainfall pattern and the associated impacts on subsistence agriculture in Laikipia East District, Kenya. Journal of Geography and Regional Planning, 5(7), 198-206.

Hurni, K., Hett, C., Heinimann, A., Messerli, P., \& Wiesmann, U. (2013). Dynamics of shifting cultivation landscapes in Northern Lao PDR between 2000 and 2009 based on an analysis of MODIS time series and Landsat images. Human Ecology, 41(1), 21-36.

Israel, G. D. (1992). Determining sample size.

Jarvis, A., Lane, A., \& Hijmans, R. J. (2008). The effect of climate change on crop wild relatives. Agriculture, Ecosystems \& Environment, 126(1-2), 13-23.

Jayne, T. S., Chamberlin, J., \& Headey, D. D. (2014). Land pressures, the evolution of farming systems, and development strategies in Africa: A synthesis. Food policy, 48, 1-17.

Joseph, C. et al. (2017) Old wine, new bottles? Investigating the differential adoption of "climate-smart" agricultural practices in western Kenya. Elsevier Ltd, 56, pp. 114-123.

Josephson, A. L., Ricker-Gilbert, J., \& Florax, R. J. G. M. (2014). How does population density influence agricultural intensification and productivity? Evidence from Ethiopia. Food Policy, 48, 142-152.

Kamat, V. (2014). "The Ocean is our Farm": Marine Conservation, Food Insecurity, and Social Suffering in Southeastern Tanzania. Human Organization, 73(3), 289-298.

Kurukulasuriya, P., \& Mendelsohn, R. (2008). Crop switching as a strategy for adapting to climate change. African Journal of Agricultural and Resource Economics, 2(311-2016-5522), 105.

Kurukulasuriya, P., Mendelsohn, R., Hassan, R., Benhin, J., Deressa, T., Diop, M. \& Mahamadou, A. (2006). Will African agriculture survive climate change? The World Bank Economic Review, 20(3), 367-388.

Lane, E. (2014). The Millennium Development Goals: a gendered critique within the context of climate change.

Lesk, C., Rowhani, P., \& Ramankutty, N. (2016). Influence of extreme weather disasters on global crop 
production. Nature, 529(7584), 84.

Lopez-Ridaura, S., Frelat, R., van Wijk, M. T., Valbuena, D., Krupnik, T. J., \& Jat, M. L. (2018). Climate smart agriculture, farm household typologies and food security: an ex-ante assessment from Eastern India. Agricultural systems, 159, 57-68.

Maddison, D. (2007). The perception of and adaptation to climate change in Africa. The World Bank.

Maddison, D. (2007). The perception of and adaptation to climate change in Africa. The World Bank.

Mahamadou, A. (2006). Will African agriculture survive climate change? The World Bank Economic Review, 20(3), 367-388.

Massetti, E., \& Mendelsohn, R. (2011). Estimating Ricardian models with panel data. Climate Change Economics, 2(04), 301-319.

Mathenge, M., Place, F., Olwande, J., \& Mithoefer, D. (2010). Participation in agricultural markets among the poor and marginalized: analysis of factors influencing participation and impacts on income and poverty in Kenya. Unpublished Study Report Prepared for the FORD Foundation.

Mati, B. M., Mutie, S., Gadain, H., Home, P., \& Mtalo, F. (2008). Impacts of land-use/cover changes on the hydrology of the transboundary Mara River, Kenya/Tanzania. Lakes \& Reservoirs: Research \& Management, 13(2), 169-177.

Maxwell, D., \& Wiebe, K. (1999). Land tenure and food security: Exploring dynamic linkages. Development and Change, 30(4), 825-849.

McCord, P. F., Cox, M., Schmitt-Harsh, M., \& Evans, T. (2015). Crop diversification as a smallholder livelihood strategy within semi-arid agricultural systems near Mount Kenya. Land Use Policy, 42, 738-750.

Meinzen-Dick, R., Quisumbing, A., Behrman, J., Biermayr-Jenzano, P., Wilde, V., Noordeloos, M., Ragasa, C., \& Beintema, N. (2010). Engendering agricultural research. IFPRI Discussion Paper 973. Washington, DC: International Food Policy Research Institute.

Mendelsohn, R. O., \& Dinar, A. (2009). Climate change and agriculture: an economic analysis of global impacts, adaptation and distributional effects. Edward Elgar Publishing.

Mendleson, N. (1994). Environmental marketing business partnering at AFC-developing strategic alliances. In Environmental marketing: Critical Success Strategies for Reaching the Green Consumer, Proceedings of the 1994 Conference, Sdyney, February (pp. 22-23).

Mugenda, O. M., \& Mugenda, A. G. (1999). Research methods: Quantitative and qualitative approaches. Acts press.

Mutus, J. Y., White, T. C., Barends, R., Chen, Y., Chen, Z., Chiaro, B., \& Neill, C. (2014). Strong environmental coupling in a Josephson parametric amplifier. Applied Physics Letters, 104(26), 263513.

Nagata, J. M., Magerenge, R. O., Young, S. L., Oguta, J. O., Weiser, S. D., \& Cohen, C. R. (2012). Social determinants, lived experiences, and consequences of household food insecurity among persons living with HIV/AIDS on the shore of Lake Victoria, Kenya. AIDS Care-Psychological and Socio-Medical Aspects of AIDS/HIV, 24(6), 728-736.

Ndobo, F. P. (2013). Determining the food security status of households in a South Afican township (Doctoral dissertation, North-West University).

Ndobo, F., \& Sekhampu, T. J. (2013). Determinants of Vulnerability to Food Insecurity in a South African Township: A Gender Analysis. Mediterranean Journal of Social Sciences, 4(14), 311-318.

Neufeldt, H., Jahn, M., Campbell, B. M., Beddington, J. R., DeClerck, F., De Pinto, A., \& LeZaks, D. (2013). Beyond climate-smart agriculture: toward safe operating spaces for global food systems. Agriculture \& Food Security, 2(1), 12.

Notter, B., MacMillan, L., Viviroli, D., Weingartner, R., \& Liniger, H. P. (2007). Impacts of environmental change on water resources in the Mt. Kenya region. Journal of Hydrology, 343(3-4), 266-278.

Odame, H., Hafkin, N., Wesseler, G., \& Boto, I. (2002). Gender and agriculture in the information society.

Osiemo, J., Jalang'o, D. A., Binge, B., Burra, D. D., Thi, H. T., Duong, T. T., \& Rubin, J. (2019). Kenya Food Systems: Summary of Available Data and Kenya Data Profile Annex.

Otsuka, K. (2013). Food insecurity, income inequality, and the changing comparative advantage in world agriculture. Agricultural Economics, 44(s1), 7-18.

Otsuka, K., \& Larson, D. F. (Eds.). (2015). In Pursuit of an African Green Revolution: Views from Rice and Maize Farmers' Fields (Vol. 48). Springer.

Parry, M. L., Canziani, O. F., Palutikof, J. P., Van der Linden, P. J., \& Hanson, C. E. (2007). Impacts, adaptation and vulnerability. Contribution of Working Group II to the Fourth Assessment Report of the Intergovernmental Panel on Climate Change (IPCC.).

Pearce, D. W., Cline, W. R., Achanta, A. N., Fankhauser, S., Pachauri, R. K., Tol, R. S., \& Vellinga, P. (1996). The social costs of climate change: greenhouse damage and the benefits of control. Climate change 1995: Economic and social dimensions of climate change, 179-224.

Pender, J., \& Gebremedhin, B. (2007). Determinants of agricultural and land management practices and impacts 
on crop production and household income in the highlands of Tigray, Ethiopia. Journal of African Economies, $17(3), 395-450$.

Pender, J., \& Gebremedhin, B. (2007). Determinants of agricultural and land management practices and impacts on crop production and household income in the highlands of Tigray, Ethiopia. Journal of African Economies, 17(3), 395-450.

Population Reference Bureau, Data Finder, August 2012. . Stata Base Reference Manual, 2013. Release 12. Stata Press Publication, StataCorp LP, College Station, Texas.

Razavi, S. (2012). World development report 2012: Gender equality and development-A commentary. Development and Change, 43(1), 423-437.

Riggs, P. K., Fields, M. J., \& Cross, H. R. (2017). Redesigning the Process for Establishing the Dietary Guidelines for Americans, 8(3), 3-4.

Samberg, L. H., Gerber, J. S., Ramankutty, N., Herrero, M., \& West, P. C. (2016). Subnational distribution of average farm size and smallholder contributions to global food production. Environmental Research Letters, 11(12), 124010.

Schmocker, J., Liniger, H. P., Ngeru, J. N., Brugnara, Y., Auchmann, R., \& Brönnimann, S. (2016). Trends in mean and extreme precipitation in the Mount Kenya region from observations and reanalyses. International Journal of Climatology, 36(3), 1500-1514.

Seo, S. N., \& Mendelsohn, R. (2008). An analysis of crop choice: Adapting to climate change in South American farms. Ecological economics, 67(1), 109-116.

Seo, S. N., \& Mendelsohn, R. (2008). An analysis of crop choice: Adapting to climate change in South American farms. Ecological economics, 67(1), 109-116.

Shalla Woreda Finance and Economic Development Office (SWFEDO) (2012). Physical and socio-economic condition of Shalla Woreda: Unpublished Document.

Siamwalla, A., \& Valdes, A. (1980). Food insecurity in developing countries. Food Policy, 5(4), 258-272.

Siamwalla, A., \& Valdes, A. (1980). Food insecurity in developing countries. Food Policy, 5(4), 258-272.

Silvestri, S., Sabine, D., Patti, K., Wiebke, F., Maren, R., Ianetta, M. Rufino, M. C. (2015).

Households and food security: Lessons from food secure households in East Africa. Agriculture and Food Security, 4(1)

Simtowe, F., Kassie, M., Asfaw, S., Shiferaw, B. A., Monyo, E., \& Siambi, M. (2012). Welfare Effects of Agricultural Technology adoption: the case of improved groundnut varieties in rural Malawi (No. 10072016-79675).

Stage, J. (2010). Economic valuation of climate change adaptation in developing countries. Annals of the New York Academy of Sciences, 1185(1), 150-163.

Tolossa, D. (2003). Issues of land tenure and food security: the case of three communities of Munessa Wereda, South-Central Ethiopia. Norsk Geografisk Tidsskrift-Norwegian Journal of Geography, 57(1), 9-19.

Warner, K., \& Afifi, T. (2014). Where the rain falls: Evidence from 8 countries on how vulnerable households use migration to manage the risk of rainfall variability and food insecurity. Climate and Development, $6(1), 1-$ 17.

WFP. (2016). Comprehensive Food Security and Vulnerability Survey: Summary report Kenya 2016. World Food Programme, 1-12.

Wiesmann U, Gichuki F, Kiteme BP, Linger HP. 2000. Mitigating conflicts over scarce water resources. Mountain Research and Development, 20: 10-15.

$\mathrm{Wu}, \mathrm{W} .$, \& Ma, B. (2015). Integrated nutrient management (INM) for sustaining crop productivity and reducing environmental impact: A review. Science of the Total Environment, 512, 415-427.

Zhai, F., Lin, T., \& Byambadorj, E. (2009). A General Equilibrium Analysis of the Impact of Climate Change on Agriculture in the People's Republic of China. Asian Development Review, Vol. 26 (1), pp. 206-225. 